\title{
59. FISSION-TRACK AGE OF VOLCANIC GLASSES FROM ASH LAYERS AT DEEP SEA DRILLING PROJECT SITE 436
}

\author{
S. S. Gansei and S. A. Gorbarenko, Laboratory of Paleogeography, Pacific Institute of Geography, \\ Far East Science Center, U.S.S.R. Academy of Sciences, Vladivostok, U.S.S.R. \\ and
}

A. N. Komarov, Laboratory of Geochronology and Isotope Geochemistry, Institute of Precambrian Geology

and Geochronology, U.S.S.R. Academy of Sciences, Leningrad, U.S.S.R.

\begin{abstract}
The fission-track technique was used to date nine samples of volcanic glasses from ash layers at Deep Sea Drilling Project Site 436. Age varied from $0.138_{-0.063}^{+0.067}$ m.y. to $12.9_{-2.61}^{+2.11}$ m.y. We annealed Sample 436-14-3 and corrected the age of annealed fossil tracks in the volcanic glass according to the resultant data. We found small differences between our age data and preliminary paleontological age data.
\end{abstract}

\section{INTRODUCTION}

This work is devoted to the dating of volcanic glasses in ash layers of DSDP Site 436, where the cored sediments are mainly Neogene and Quaternary. We selected ten samples with maximal content of fresh volcanic glass. The content of volcanic glass varied from 50 per cent in Section 436-30-1 to 90 per cent in Section 436-14-3 and averaged 75 to 80 per cent. We selected grains larger than $0.1 \mathrm{~mm}$. The grains measured 100 to $300 \mu \mathrm{m}$ in length and varied greatly in width, which was in some samples as small as 20 to $40 \mu \mathrm{m}$.

\section{MATERIALS AND METHODS}

In this work we used the technique suggested by Fleischer and Price (1964) for preparation and geological dating of volcanic glass. Two aliquots of glass grains were mounted in epoxy in several packed layers, one mount for fossil-fission-track counting and the other for induced-fission-track counting. We found by repeated experiments that the number of grains in mounts from one and the same sample prepared for spontaneous (fossil) and induced tracks varied not more than 6 per cent. Track density was calculated for the whole surface of the mount. Mounts were etched in HF $(48 \%)$ at $21^{\circ} \mathrm{C}$ for 10 seconds. After etching, the sample from Section 436-5-2 was discarded, because the grains were covered with a troublesome layer of "slime" that prevented counting of the tracks.

For producing induced tracks, the second mount was irradiated by thermal neutrons. The thermal-neutron dose was measured by mica detectors, with a precisely known quantity of uranium. Mica detectors were placed at each end of the set-up. The neutron flux was $3.1 \pm$ $0.08 \times 10^{14} \mathrm{n} / \mathrm{cm}^{2}$.
Age was calculated by the formula

$$
t=\frac{P_{s} N}{P_{i} C \epsilon \lambda_{s}},
$$

where

$P_{i} \quad$ is the induced-track density,

$P_{s} \quad$ is the spontaneous-track density,

$C^{s}$ is the quantity of uranium on detector standard,

$\epsilon \quad$ is the effectivity of track registration by the detector,

$\lambda_{s} \quad$ is the fission-decay constant for ${ }^{238} \mathrm{U}$,

$N \quad$ is the number of induced tracks counted by detector.

In the equation, $\lambda_{s}$ equals $7.03 \times 10^{-17} \mathrm{yr}^{-1}$ (Roberts et al., 1968). We calculated the density of spontaneous tracks and then of induced tracks in transmitted light at $\times 460$ magnification. Together with track density, we measured the length of the etch pits. On these results, we constructed a histogram of diameters of fission-track etch pits (Figure 1) for each sample, except that from Section 436-3-4, which had only a small number of fossil tracks.

The error in dating $(1 \sigma)$ was calculated from the root mean square error in the count of spontaneous and induced tracks, plus the correction of track density as a result of annealing and the error resulting from uneven packing of grains in mounts.

\section{INTERPRETATION AND CONCLUSIONS}

Histograms of etch-pit diameters show that the mode for spontaneous-track values is less than the mode for 


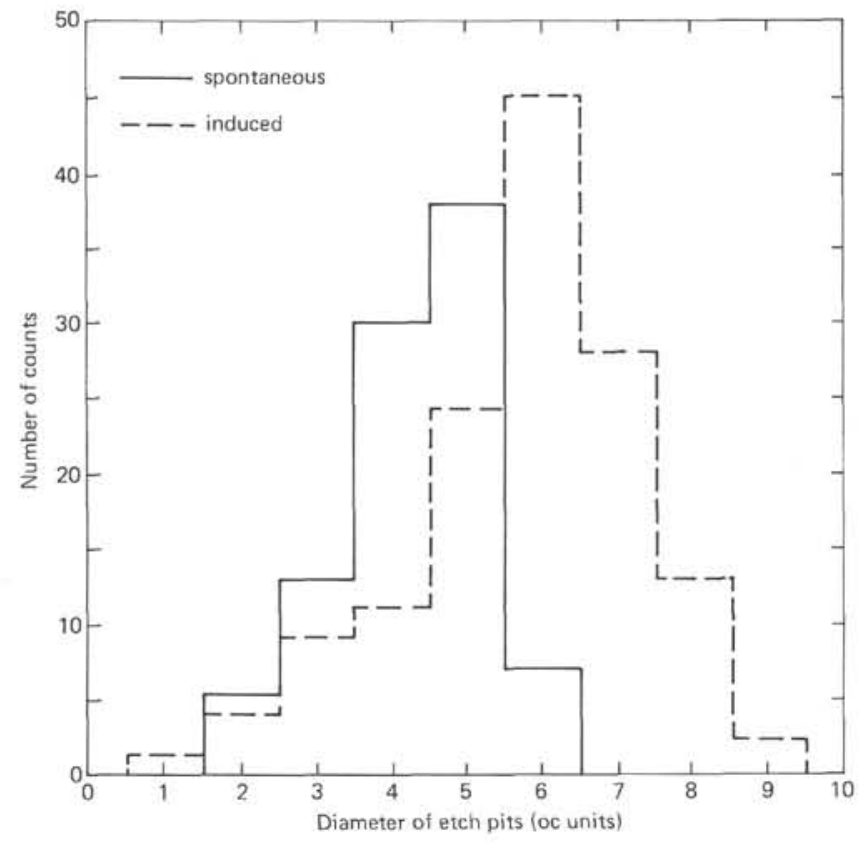

Figure 1. Distribution of diameters of fission-track etch pits in volcanic glass. (1 oc unit $=1.11 \mu \mathrm{m}$.) Section 436-14-3.

induced tracks (Figure 1). This means that the size and number of tracks decreased as a result of uniform natural annealing. The preservation of spontaneous tracks is determined by various factors of the environment, such as temperature and pressure, and also by the chemical composition of the glass, the amount of water it contained, and its geological time of formation (Fleischer et al., 1975). Probably the main factors determining the degree of annealing of volcanic glasses from ash layers of Site 436 were temperature and time of formation.

Experimental determination of the size-density ratio of the tracks allowed us to find the original number of fossil tracks and to calculate their true age. To correct the density of spontaneous tracks, we used the size-density curve for tracks induced by thermal annealing of volcanic glass from Section 436-14-3 (Figure 2). The curve we plotted was quite different from the theoretical curve for glass (Somogyi and Nagy, 1972) and from the experimental curves. Our curve is similar to the one produced by Storzer and Wagner (1971) in the annealing of bediasites. Both these curves have a typical inflection point in the upper part, registering a strong lag in the size reduction of the tracks in comparison with their density loss.

In the seven youngest samples, the loss of fossil tracks was about the same (21-26\%), in spite of a rather large range of age variation (excluding the sample from Section 436-19-9, which had $11 \%$ density reduction). The density loss in two oldest fossil-track samples, from Sections 436-30-1 and 436-34-5 (ages 5.8 m.y. and 12.9 m.y.), was greater (62 and $65 \%$, respectively). Probably this greater loss in the two oldest samples can be explained by their earlier formation (Table 1).

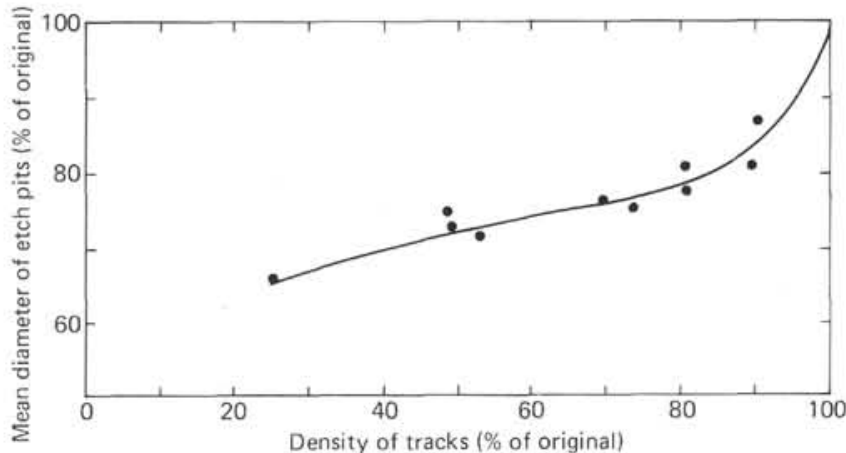

Figure 2. Dependence of mean diameter of fissiontrack etch pits on track density when annealed $(100 \%$ stands for tracks before annealing). Section 436-14-3.

The samples from Site 436 covered the geological history of sedimentation in this region from late middle Miocene through the Pleistocene. We have plotted a curve of sediment accumulation based on our age data (Figure 3). This curve corroborates preliminary paleontological age data, using the time scale of Berggren and van Couvering (1974).

The sediment-accumulation rate of the late middle Miocene and early late Miocene (represented by sediments near the boundary of lithologic units IIIB and IV) was small, $\left(0.5 \mathrm{~cm} / 10^{3} \mathrm{yr}\right)$, which is typical of pelagic sedimentation with very little influx of terrigenous material and ash (Lisitzin, 1974). During the middle Miocene and the earliest Pliocene (unit IIIB and the lower part of unit IIIA), the sediment accumulation rate gradually increased; by the middle of the early Pliocene it had reached about $10 \mathrm{~cm}$ per thousand years and thereafter changed very little. This rise in the sedimentation rate and the change in sediment composition (Site 436 report, this volume) in the interval from 13 to $3 \mathrm{Ma}$ indicate a definite change in the mode of sediment accumulation. During this time, the influx of terrigenous material and ash increased, as did biogenic components of the sediments.

\section{REFERENCES}

Berggren, W. A., and van Couvering, J. A., 1974. The late Neogene biostratigraphy, geochronology and paleoclimatology of the last 15 million years in marine and continental sequences. Palaeogeogr., Palaeoecol., Palaeoclimat., 16, 1-216.

Fleischer, R. L., and Price, P. B., 1964. Glass dating by fission fragment tracks. J. Geophys. Res., 69, 331.

Fleischer, R. L., Price, P. B., and Walker, R. M., 1975. Nuclear Tracks in Solids: Berkeley (Univ. Calif. Press).

Lisitzin, A. P., 1974. Sedimentation in the Ocean: Moscow (Nauka).

Roberts, J. H., Gold, R., and Armani, R. J., 1968. Spontaneous fission decay constant of uranium-238. Phys. Rev., Ser. 2, 174, 1482-1484.

Somogyi, G., and Nagy, M., 1972. Remarks on fission-track dating in dialectric solids. Radiation effects, 16, 223-231.

Storzer, D., and Wagner, G. A., 1971. Fission track ages of North American tectites. Earth and Planet. Sci. Lett., 10, 435-440. 
TABLE 1

Fission-Track Ages of Volcanic Glass in Ash Layers, Site 436

\begin{tabular}{|c|c|c|c|c|c|c|c|c|}
\hline \multirow{2}{*}{$\begin{array}{l}\text { Section } \\
436-3-4\end{array}$} & \multirow{2}{*}{$\begin{array}{c}\begin{array}{c}\text { Sub-bottom } \\
\text { Depth } \\
(\mathrm{m})\end{array} \\
21.0\end{array}$} & \multirow{2}{*}{$\begin{array}{c}\begin{array}{c}\text { Number of } \\
\text { Spontaneous } \\
\text { Tracks }\end{array} \\
5\end{array}$} & \multirow{2}{*}{$\begin{array}{c}\begin{array}{c}\text { Spontaneous } \\
\text { Tracks } / \mathrm{cm}^{2}\end{array} \\
2.04 \pm 0.97\end{array}$} & \multirow{2}{*}{$\begin{array}{c}\begin{array}{c}\text { Induced } \\
\text { Tracks } / \mathrm{cm}^{2} \times 10^{2}\end{array} \\
3.63 \pm 0.39\end{array}$} & \multirow{2}{*}{$\begin{array}{c}\begin{array}{c}\text { Measured Age } \\
(\mathrm{m} . \mathrm{y} .)\end{array} \\
0.109 \pm 0.05\end{array}$} & \multicolumn{2}{|c|}{$\begin{array}{l}\text { Thermal Reduction of Tracks } \\
\text { Dimension Density } \\
\text { ( } \% \text { of original) }\end{array}$} & \multirow{2}{*}{$\begin{array}{c}\begin{array}{c}\text { Corrected Agc } \\
(\mathrm{m} . \mathrm{y})\end{array} \\
0.138_{-0.063}^{+0.067}\end{array}$} \\
\hline & & & & & & $77.7 \pm 3.5$ & $\begin{array}{l}79^{+7} \\
-14\end{array}$ & \\
\hline $436-7-2$ & 57.5 & 43 & $14.9 \pm 0.27$ & $4.32 \pm 0.32$ & $0.671 \pm 0.112$ & $76.0 \pm 2.6$ & $74_{-15}^{+7}$ & $0.906_{-0.174}^{+0.738}$ \\
\hline $436-9-5$ & 81.0 & 175 & $93.6 \pm 8.9$ & $20.68 \pm 1.06$ & $0.879 \pm 0.084$ & $76.6 \pm 1.8$ & $74_{-9}^{+5}$ & $1.19^{+0.18}-0.14$ \\
\hline $436-14-3$ & 126.0 & 174 & $128.8 \pm 12.3$ & $18.6 \pm 0.90$ & $1.344 \pm 0.128$ & $77.2 \pm 2.2$ & $77.5_{-8}^{+5.5}$ & $\begin{array}{l}1.73+0.24 \\
-0.21\end{array}$ \\
\hline $436-15-7$ & 140.5 & 104 & $90.1 \pm 10.6$ & $12.4=0.80$ & $1.419 \pm 0.170$ & $78.5 \pm 2.2$ & $78.5_{-7.5}^{+5}$ & $1.81^{+0.28}=0.25$ \\
\hline $436-19-9$ & 178.5 & 43 & $26.4 \pm 4.6$ & $2.57 \pm 0.20$ & $1.995 \pm 0.341$ & $83.7 \pm 3.5$ & $\begin{array}{r}89+3.5 \\
-4.5\end{array}$ & $2.24^{+0.40}-0.39$ \\
\hline $436-22-1$ & 199.0 & 117 & $145 \pm 17.7$ & $13.9 \pm 0.89$ & $2.024 \pm 0.23$ & $77.6 \pm 2.2$ & $\begin{array}{r}79+4.5 \\
-7.5\end{array}$ & $2.56_{-0.41}^{+0.45}$ \\
\hline $436-30-1$ & 275.0 & 124 & $52.3 \pm 5.7$ & $4.64 \pm 0.28$ & $2.192 \pm 0.241$ & $69.6 \pm 1.9$ & $38_{-5.5}^{+7.5}$ & $5.8_{-1.3}^{+1.1}$ \\
\hline $436-34-5$ & 318.0 & 360 & $357 \pm 2.6$ & $15.5 \pm 0.80$ & $4.499+0.356$ & $68.7 \pm 1.9$ & $35_{-5}^{+6.5}$ & $\begin{array}{r}12.9^{+2.1} \\
-2.6\end{array}$ \\
\hline
\end{tabular}

${ }^{a}$ Track density was calculated for the whole area of the mount; errors of $P_{S}$ and $P_{i}$ include errors in the count of the tracks and errors from uneven packing of grains in the mount.

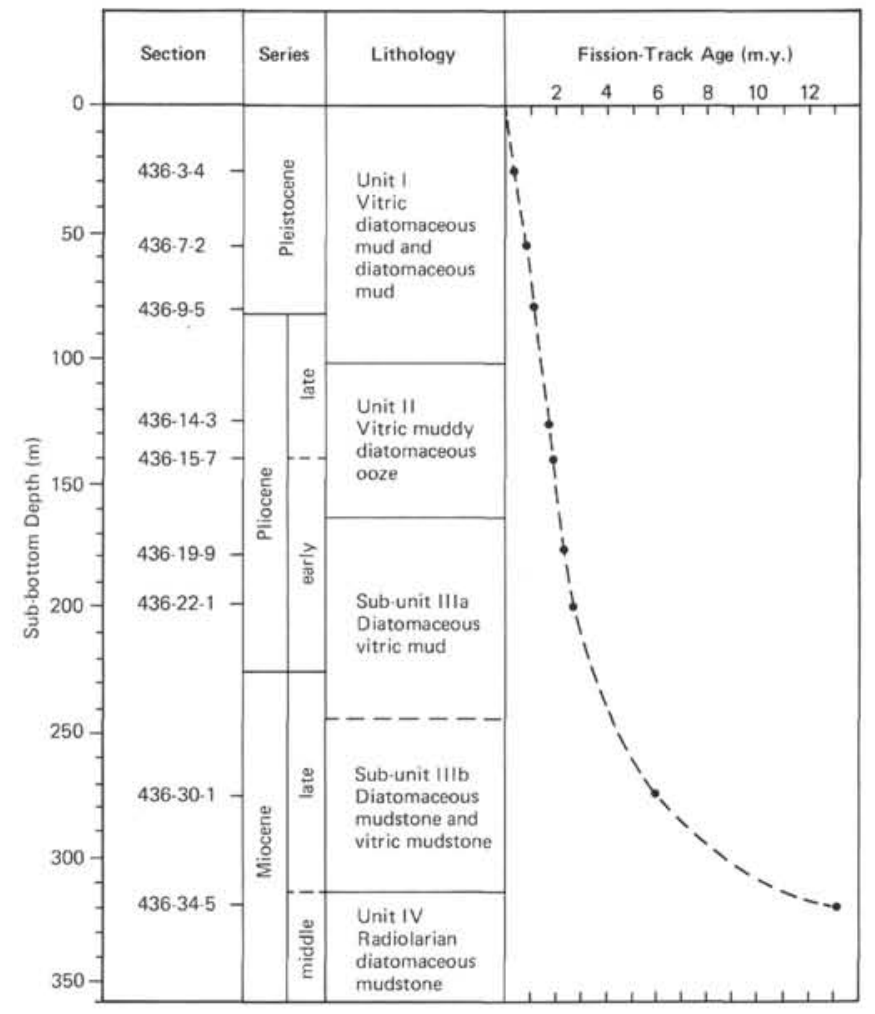

Figure 3. Sediment accumulation rate at Site 436, according to fission-track ages. 